\title{
Sustainable Utilization of Ultrasonic Radiation in Extraction and Dyeing of Wool Fabric Using Logwood (Haematoxylum Campechianum) Extract
}

\author{
Muhammad Azeem ${ }^{1}$, Shahid Adeel ${ }^{2}$, Noman Habib ${ }^{1}$, Fazal-ur-Rehman ${ }^{2}$, Ameer Fawad Zahoor ${ }^{3}$, \\ Madiha Saeed ${ }^{1}$, Nimra Amin' ${ }^{2}$, Salman Liaqat ${ }^{2}$, Muhammad Hussaan ${ }^{1}$ \\ ${ }^{1}$ Department of Botany, Government College University Faisalabad 38000, Pakistan \\ ${ }^{2}$ Department of Applied Chemistry, Government College University Faisalabad 38000, Pakistan \\ ${ }^{3}$ Department of Chemistry, Government College University Faisalabad 38000, Pakistan
}

Corresponding Author: Shahid Adeel, shahidadeel@gcuf.edu.pk

\begin{abstract}
Environmental regulations imposed by world renowned associations have forced the global community to use eco-friendly and sustainable dyed products in applied fields. The current study has been concerned with the effect of ultrasonic radiation on the extraction of Hematein from logwood and its application onto wool fabric. Where the extraction was carried out by boiling respective amount of powder into methanolic medium, the extract obtained and wool fabrics were treated with ultrasonic radiation for 15, 30, 45 and 60 min. Dyeing of irradiated and un-irradiated fabric was carried out using irradiated and un-irradiated extracts at $70{ }^{\circ} \mathrm{C}$ for $45 \mathrm{~min}$. keeping material to liquor ratio of 1:25. For improvement in shades, salts of aluminum, iron and tannic acid as chemical mordants and extracts of Zeera (Cuminum cyminum), Harmal(Peganumharmala) and Turmeric (Curcuma longa) as source of bio mordants have been employed at $70{ }^{\circ} \mathrm{C}$ for $45 \mathrm{~min}$. keeping fabric to mordant ratio of $1: 25$. It is found that extract after Ultrasonic treatment (US) for $45 \mathrm{~min}$. has given acceptable results. The colour strength results show that $1 \% \mathrm{Al}, 3 \% \mathrm{Fe}$, and $7 \%$ Tannic acid as pre- chemical mordants, where as before dyeing $7 \%$ of Zeera, Harmal and turmeric extracts have given excellent color coordinates, Similarly $1 \% \mathrm{Al}$, $7 \% \mathrm{Fe}$, and $7 \%$ Tannic acid as post- chemical mordants, where as after dyeing $3 \%$ of Zeera, $7 \%$ Harmal and $7 \%$ Turmeric have given good color characteristics at mild conditions. It is inferred that ultrasonic treatment has enhanced the coloring behaviour of wool using hematein extracted from logwood chips.
\end{abstract}

\section{ARTICLE HISTORY}

Received: 06.07.2018

Accepted: 06.02.2019

\section{KEYWORDS}

Bio-mordant, hematein, logwood, ultrasonic radiation, wool

\section{INTRODUCTION}

After the discovery of chemical dyes by "Perkin" chemical dyes have completely replaced the usage of natural dyes for coloring purpose $(1,2)$. Due to the awareness of the ecological and other health problems that are associated with production and frequent usage of chemical dyes in different fields, a worldwide attention to textile industry for the use of natural dyes rather than chemical dyeshas emerged $(3,4)$. In recent years, the use of natural dyes has gained a mildermomentum due to increased utilization of natural dyes in various fields such as cosmetic, food product, pharmaceutical and in the textile industry as well $(5,6)$. Moreover, the natural plants-based dyeshave antibacterial, antifungal and antioxidant properties $(7,8)$. Natural dyes are mostly used with mordant so that dye can stick to the fabrics (cotton, wool and silk). Mordants are

To cite this article: Azeem, M., Adeel, S., Habib, N., Rehman, F., Zahoor, A.F., Saeed, M., Amin, N., Liaqat, S., Hussaan, M. 2019. Sustainable utilization of ultrasonic radiation in extraction and dyeing of wool fabric using logwood (haematoxylum campechianum) extract. Tekstil ve Konfeksiyon, 29(2), 181-186. 
used to enhance the color strength of dyed material and to increase the fastness properties and also produce plenty of shades. Commonly two types of mordants are used, first ones are metallic mordants (such as copper, Iron, alum and tannic acid) $(9,10)$. Second ones are bio mordants (such as harmal, zeera, turmeric) $(11,12)$.

Extraction process plays an important role for compatibility of natural dyes with fabrics because the quality of extract depends on many factors such as plant source, extraction treatment, types and quantity of solvents. During extraction, the coloring matter from dyeing material is transferred to the solvent which give brilliant colors to the fabric. Extraction of dye can be improved by employing various techniques such as microwave treatment $(13,14)$, usage of enzyme technique (15), UV exposure $(16,17)$ and ultrasonic treatment $(18,19)$, plasma treatments $(20,21)$ and gamma irradiation (22). Ultrasonic assisted extraction (UAE) technique involves interaction of high frequency and high intensity sound waves used for vibration, collision and diffusion of material out of solid phase under the effect of acoustic cavitations (23). Its intensity is based on the efficiency that reaches a point where intermolecular forces break out to free the solvent molecules to facilitate the release of extractable compounds and enhanced penetration through the membrane (24). It is more economical, time saving, eco friendly and produced desirable shades there by increasing the color strength of dyed material (25). Further, the cell wall can easily be ruptured by sonication that also facilitates in release of phytochemical thereby improving the extraction efficiency (26).

Logwood (Haemtoxylumcampechianum) is good source of natural dye for wool dyeing. It belongs to legume family fabaceae. Its main colouring component in wood is hematein (structure given below) that is formed by oxidation of haematoxylum (27). Naturally, haematoxylin when present in plant is colorless and its different staining colors are due to its oxidized form i-e Hematein. Logwood plant has rapid growth with crooked spinous leaves and branches, flowers have raceme in fluorescence and leaves are pinnate (28). Logwood colorant (hematein) interacts with different mordant such as with iron to produce grey shade, with copper to produce green or blue shade and with aluminium to give violet or grey shades. The bark and gum of logwood plant has been used as a stringent and as a treatment for dysentery (29).

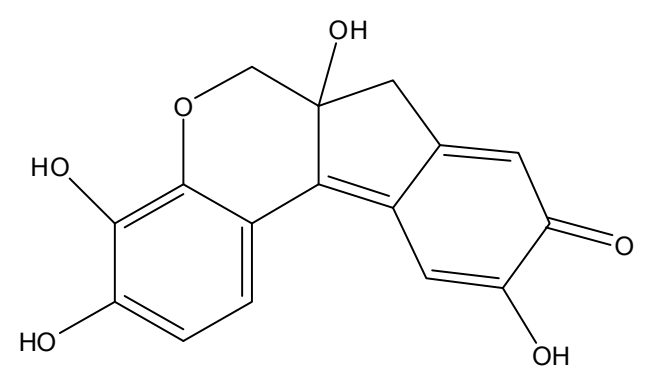

The aims of current study:

- To improve extraction of colorant (hematein) from logwood chips under the influence of ultrasonic radiations.
- To improve color strength and colorfastness of wool fabric dyed with hematein extracted from log wood chips using ultrasonic irradiation.

\section{MATERIAL AND METHOD}

\subsection{Material}

Logwood (Haemtoxylum campechianum) chip have been provided by Linhtran Design House, Thailand. The chips were washed well with distilled water to remove the impuritirs like dirt and dried under shade. The dried chips were sharply chopped into very small pieces and ground finely using grinding machine followed by meshing upto 20 for fine grains. Wool fabric $\left(106 \mathrm{~g} / \mathrm{m}^{2}\right)$ was purchased from the Faisalabad Textile Market, Pakistan. Commercial grade chemicals such as sodium hydroxide, concentrated hydrochloric acid, methanol, table salt, Glauber's salt, tannic acid, aluminum sulphate and iron sulphate used wereof Pakistan made. Zeera (Cuminumcyminum), harmal (Peganumharmala) seeds and turmeric (Curcuma longa) rhizomes have been purchased from herbal market of Faisalabad, Pakistan. These plant sources of bio-mordants were washed well and dried under shade.

\subsection{Extraction and Irradiation Process}

Extraction of hematein from logwood was carried out by boiling powder $(4 \mathrm{~g})$ with organic medium $(100 \mathrm{~mL}$ methanol). After boiling, the mixture was filtered through fine muslin cloth thricely and the filtrate obtained was used for further dyteing and mordanting experiments. To get improved isolation yield of hematein onto wool fabric, both extracts and wool fabrics were given ultrasonic treatment for $15,30,45$, and $60 \mathrm{~min}$. at $60{ }^{\circ} \mathrm{C}$ using a RoHS Ultrasonic Irradiator (220 V; $40 \mathrm{kHz}$ ) at Eco-Friendly Textile Lab., Govt. College University Faisalabad, Pakistan.

\subsection{Dyeing and Mordanting Conditions}

After extraction, un-irradiated (NRE) and US treated extracts (RE) were used to dye US treated wool (RW) and un-irradiated wool fabric (NRW) at $80^{\circ} \mathrm{C}$ for $45 \mathrm{~min}$. keeping wool fabric to logwood extract ratio of 1:25. After getting optimal dyeing condition, the fabrics were subjected to chemical and bio-mordanting at given conditions. For this purpose $1-5 \%$ of eco-friendly chemical mordants such as aluminum sulphate $\mathrm{Al}_{2}\left(\mathrm{SO}_{4}\right)_{3}$, iron sulphate $\mathrm{FeSO}_{4}$ and tannic acid (TA) and 1-5\% of extracts of bio-mordant such as Zeera, Harmal, Turmeric were applied during pre and post mordanting process at $80{ }^{\circ} \mathrm{C}$ for 45 min keeping fabric to biomordant extract ratio of 1:25. Extraction of biomordants from the plant sources was carried out by boiling powder $(4 \mathrm{~g})$ in $100 \mathrm{ml}$ water keeping mordant to solvent ratio of $1: 25(30)$.

\subsection{Evaluation of Characteristics of Dyed and Undyed Fabrics}

The relative color strength $(\mathrm{K} / \mathrm{S})$ and color coordinates $\left(L^{*}, a^{*}\right.$ and $b^{*}$ values) of dyed wool fabrics were investigated in spectra flash SF 600 haing D $6510^{\circ}$ observer illuminant art department of Applied Chemistry. 


\section{RESULTS AND DISCUSSION}

Ultrasonic radiation (US) in extraction has played a great role in isolation of biological active component (Hematein) from logwood. It is found that US treatment to methanolic extract for 45 min has given darker shades when unirradiated wool is used to dye (Figure 1). Low US treatment time does not causes significant cavitation for mass transfer into solvent (30). Whereas for long US treatment time, the cavitations causes vibrational energy to sphere of cell wall (31), which evolve other moieties along with colorant into solvent. Upon dyeing, these extracted bio molecules affect the coloration of wool. The role of solvent also shows the significant effect, as methanol has high dissipation power than aqueous and acidic medium, so it evolves the Hematein more efficiently upon Ultrasonic treatment (32). Ultrasonic treatment for $45 \mathrm{~min}$. causes excellent acoustic cavitations which via mass transfer kinetics makes the solid liquid interaction promisingly toextract the colorant more into solvent (33). Thus it has been inferred that methanolic extract for 45 min should be used US treatment to dye unirradiated wool for getting darker shade.

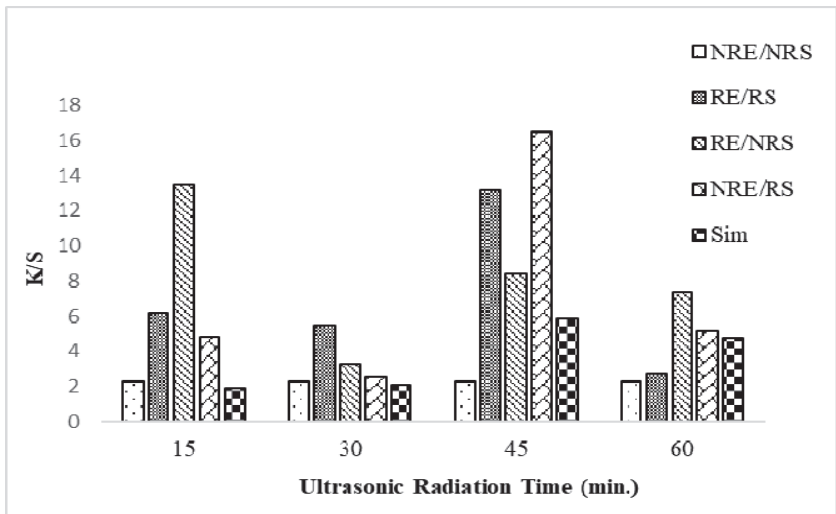

Figure 1. Effect of ultrasonic irradiation time on extraction of hematein from log wood and its dyeing onto wool fabric

Bio-mordants have find their application in improving the shade as well as fastness characteristics (34). These bioactive molecules possess ayuervedic and ecofriendly nature and enhance the color characteristics through extra bonding with $-\mathrm{OH}$ of colorant and amido linkage of wool (35). According to result given in Figure 2, it has been observed that among bio-mordants used $7 \%$ of turmeric, $7 \%$ from harmal and $3 \%$ of zeera has given acceptable results onto un-irradiated wool. Similarly, among chemical mordants used $5 \%$ of $\mathrm{Al}, 3 \%$ of $\mathrm{Fe}$ and $7 \%$ of tannic acid have given excellent color strength. This is because the biomordants having $-\mathrm{OH}$ group available for intermolecular $\mathrm{H}$ bonding with $-\mathrm{OH}$ of colorant and covalent bonding with amide linkage of wool have enhanced the dyeing behaviorafter US treatment. The good metal dye complex formation onto wool fabric is attributed to complex power as well as reduction power (36).Thus, during pre mordanting, bio-mordanting have given relatively good results as compared to chemical mordanting onto fabric using us treatment in irradiated methanolic extract of logwood chips. In post mordanting the leveled dyeing play the role because dyed surface evenly sorb the molecule salts to form coordinate covalent bond $(1,37,38)$. It has been observed
$3 \%$ of $\mathrm{Al}, 7 \%$ of Iron and tannic acid has given acceptable coloring strength. However $3 \%$ of zeera, $7 \%$ ofhermal and turmeric has given much darker shade as compared to chemical mordanting used (Figure 3). The overall dyeing post mordanting bio-mordants has given excellent color characteristics when methanolic extract is used to dye irradiated wool at optimum conditions.

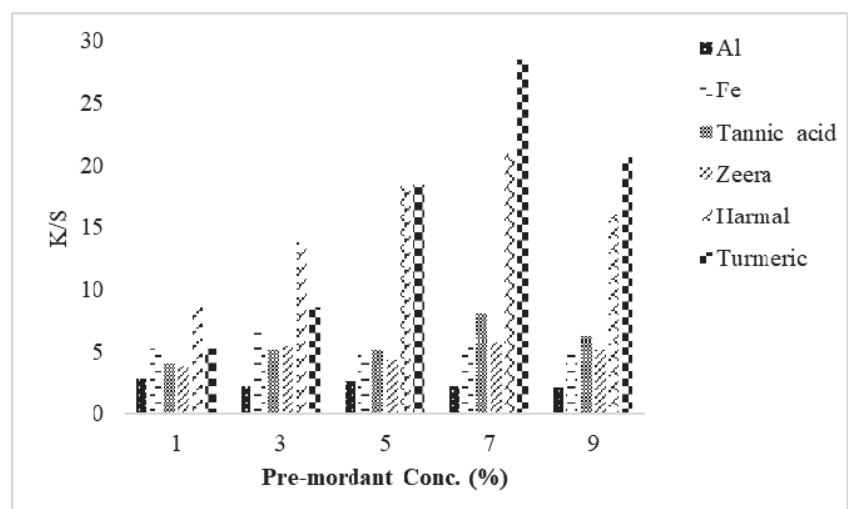

Figure 2. Effect of pre-chemical and bio- mordanting on colour strength of wool fabric dyed with US treated log wood extract

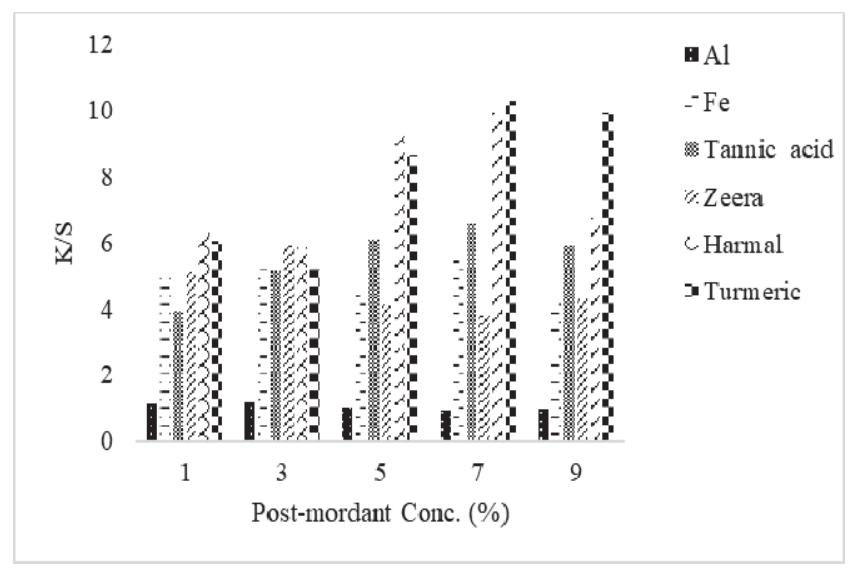

Figure 3. Effect of post chemical and bio- mordanting on colour strength of wool fabric dyed with US treated log wood extract

The color coordinates $\left(L^{*}, a^{*}\right.$ and $b^{*}$ values) given in Table 1 for pre mordants and Table 2 for post mordants show that using chemical mordants the dyed fabrics are more brighter, redder and yellower in shade but upon various biomordants, the sample dyed are much more brighter, much more redder and yellower in shade. Similarly, during post mordanting the lab values given in Table 2 show that mostly fabric dyed using chemical mordants are more redder, more brighter and more yellower in shade, hence during post biomordanting samples are less redder, darker but more yellower in shade. But overall, during post mordanting samples are darker in shade having yellowish red tone. Hence over all US treatment have not only given acceptable results but also good color coordinated when extract of logwood have expressed firm shade onto wool. 


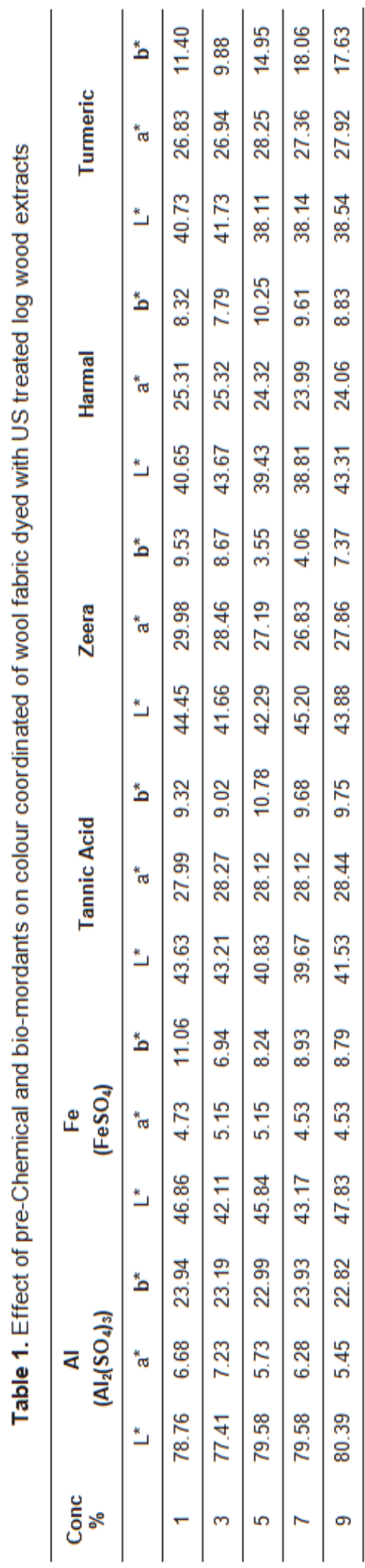

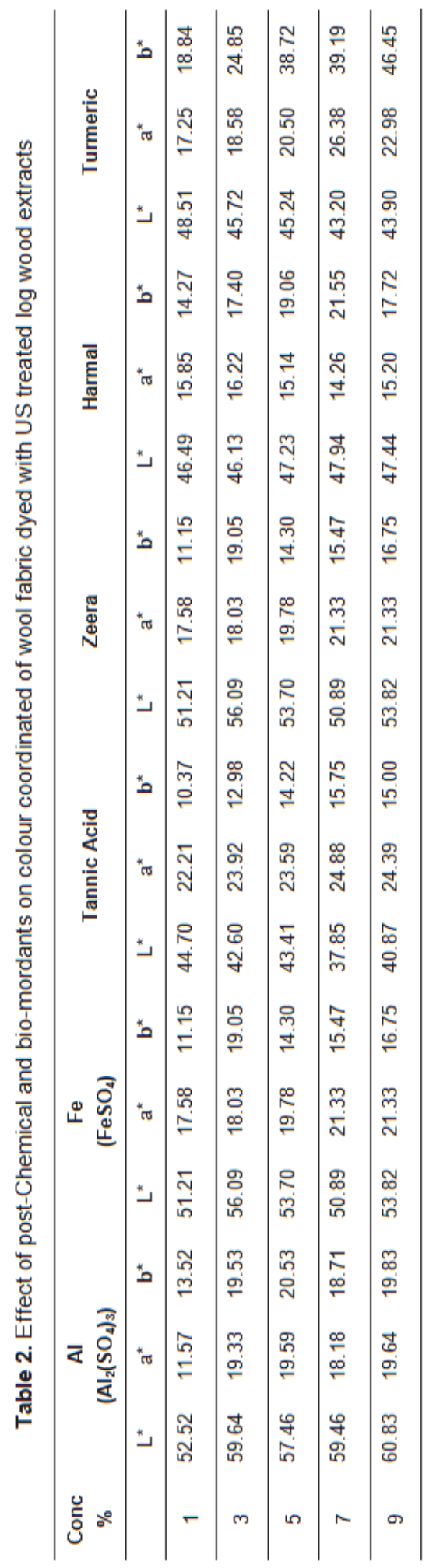




\section{CONCLUSION}

With increase in globalization, the concept of environmental friendly products in every walk of life in gaining fame due to their sustainable and herbal nature. The utilization of such products particularly, plant based colorants in textiles, their isolation using clean and green technologies such as ultrasonic treatment and improvement in their coloring behavior using bio-mordants are under observation for their frequent usages. The current study has been conducted to make possible use of natural colourant (Hematein) isolated from logwood through ultrasonic treatment and its application onto wool fabric by implementation of ecofriendly chemical and bio-mordants. It is found that extract after US treatment for $45 \mathrm{~min}$ has given good color strength onto un-irradiated wool. The excellent coloring results show that $1 \% \mathrm{Al}, 3 \% \mathrm{Fe}, 7 \%$ Tannic acid , where as $7 \%$ of Zeera, Harmal and Turmeric extracts before dyeing have given good tinctorial strength and excellent color coordinates. Similarly $1 \% \mathrm{Al}, 7 \% \mathrm{Fe}, 7 \%$ Tannic acid, where as $3 \%$ of Zeera, $7 \%$ of Harmal and $7 \%$ of Turmeric extracts after dyeing have given good color characteristics at mild conditions, hence ultrasonic radiation, being clean and sustainable tool has not only reduced the amount of mordants used but also improved the dyeing behavior of hematein isolated form logwood.

\section{Acknowledgements}

We are also thankful to Mr. Zafar Iqbal, Manager Quality Control Laboratory, Noor Fatima Fabrics (Pvt). Faisalabad, Pakistan and Mr. Muhammad Abbas, Haris Dyes and Chemicals, Faisalabad, Pakistan for providing us the technical assistance to conduct the research at lab scale.

\section{REFERENCES}

1. Haddar, W., M. Ben Ticha, N. Meski, A. Guesmi. "Application o anthocyanins as natural dye extracted from Brassica oleracea I. var. capitata f. rubra: dyeing studies of wool and silk fibres". Nat. Prod. Res., 32(2): 141-148, 2018

2. Rehman, F., S. Adeel, R. Hanif, M. Muneer, K.M. Zia, M. Zuber, M.A Jamal, M.K. Khosa. "Modulation of marigold based lutein dye and its dyeing behaviour using uv radiation".J. Nat. Fibers., 14(1): 63-70, 2017.

3. Adeel, S., S. Rafi, M. Salman, F.U. Rehman, S. Abrar. "Potential resurgence of natural dyes in applied fields." Wiley Scrivener Publishing LLC USA edn 1st, 1-26, 2017.

4. Shabbir,M., S.U. Islam, M.N. Bukhari, L.J. Rather, M.A. Khan, F. Mohammad. "Application ofTerminalia chebula natural dye on wool fiber-evaluation of color and fastness properties". Text. Cloth. Sustain., 2(1): 1-9, 2017

5. Turemen, M., and A. Demir. "Analysis of biopolymer application on cotton fabrics by different methods." J. Text. Apparel/Text. Konfeksiyon., 27(4): 366-372, 2017

6. Adeel, S., S. Abrar, S. Kiran, T. Farooq, T. Gulzar, M. Jamal "Sustainable application of of natural dyes in cosmetic Industry". Handbook of renewable materials for coloration and finishing Wiley Scrivener Publishing LLC USA. edn1st, 189-212, 2018.

7. Ado, A., H. Yahaya, A.A. Kwalli, R.S. Abdulkadir. "Dyeing of textiles with eco-friendly natural dyes: A review". Int. J.Environ. Monit. Protec. 1(5): 76-81, 2014.

8. Tolek, S., and F. Doba Kadem "An ınvestigation on colour analysis and fastness properties of the denim fabric dyed with a different method". J Text. Apparel/Tekst Konfeksıyon., 26(2): 198-204, 2016.

9. Rehman, F.U., S. Adeel, S. Rafi, N. Habib, K.M. Zia, M. Zuber, N. Akhtar."Contemporary revolutions in natural dyes: extraction and dyeing methodology. Handbook of renewable materials for coloration and finishing”.Wiley Scrivener Publishing LLC USA. Edn 1st, 126-168, 2018.

10. Bukhari, M.N., S.U. Islam, M. Shabbir, L.J. Rather, M. Shahid, U. Singh M.A. Khan, F. Mohammad. "Dyeing studies and fastness properties of brown naphtoquinone colorant extracted from Juglans regia I on natural protein fiber using different metal salt mordants." Text. Cloth. Sustain., 3(3): 3-9, 2017.

11. Adeel, S., S. Rafi, M. Azeem, M. Salman, N. Iqbal, M. Zuber "Resurgence of natural dyes:Ideas and technologies for textile dyeing". Handbook of textile colorationand finishing, LLC Stadium Press USA., 1-27, 2018.

12. Kale, M.J., N.V. Bhat."Effect of microwave pretreatment on the dyeing behaviour of polyester fabric". Color Technol., 127(6): 365-271, 2011.

13. Asofiei, I., I. Calinescu, A. Trifan, I.G. David, A.I. Gavrila. "Microwave assisted batch extraction of polyphenols from sea buckthorn leaves".Chem. Eng. Commun.,203(12): 1547-1553, 2016.
14. Dickson, S.P., K. Wang, I. Krantz, H. Hakonarson, D.B. Goldstein. Rare variants create synthetic genome-wide associations". Plos Biol., 8(1): $655-674,2010$

15. Gorjanc, M., M. Mozetic, A. Vesel, R. Zaplotnik. "Natural dyeing and uv protection of plasma treated cotton". Eur Phys J. D., 72(41):2-6, 2018.

16. Diaz-Cruz, M.S., P. Gago-Ferrero, M. Llorca, D. Barcelo. "Analysis of UV filters in tap water and other clean waters in spain”. Anal. Bioanal. Chem., 402(7): 2325-2333, 2012.

17. Kamel, M.M. M.M. El-Zawahry, N.S.E. Ahmed, F. Abdelghaffar "Ultrasonic dyeing of cationized cotton fabric with natural dye, part 1 : cationization of cotton using solfix e."Ultrason. Sonochem.,16(2): 243 249, 2009

18. Haji, A., M.K. Mehrizi, J. Sharifzadeh. "Dyeing of wool with aqueous extract of cotton pods improved by plasma treatment and chitosan: optimization using response surface methodology". Fibers Polym., 17(9): 1488-1488, 2016

19. Adeel, S., T. Gulzar, M. Azeem, F.U. Rehman, M. Saeed, I. Hanif, N lqbal. "Appraisal of marigold flower based lutein as natural colourant for textile dyeing under the influence of gamma radiations". Radiat. Phys. Chem, 130: 35-39, 2017

20. Dai, J., R.J. Mumper. "Plant phenolics: extraction analysis and their antioxidant and anticancer properties".Molecules., 15(10): 7313-7352, 2010.

21. Baaka, N., A. Mahfoudhi, W. Haddar, M.F. Mhenni, Z. Mighri. "Green dyeing process of modified cotton fibres using natural dyes extracted from Tamarixaphylla (L.) Karst. Leaves". Nat. Prod. Res., 31(1): 22-31, 2016.

22. Baaka, N., W. Haddar, M.B. Ticha, M.T.P. Amorim, M.F. Henni. "Sustainability Issues of ultrasonic wool dyeing with grape pomace colourant". Nat. Prod. Res., 31(14): 1655-1662, 2017.

23. Peng, L.Q., J. Cao, L.J. Du, Q.D. Zhang, J.J. Xu, Y.B. Chen, R.R. Li "Rapid ultrasonic and microwave assisted micellar extraction of zingiberone." shogaol and gingerols from gingers using biosurfactants". J. Chromatogra. A., 1515: 37-44, 2017.

24. Titford, M. "The Long History of Haematoxylin." Biotech. Histochem., 80(2): 73-78, 2005

25. Bouatay, F., N. Baaka, S. Adeel, M.F. Mhenni. "A novel natural vicia faba I. membranes as colourant: development and optimization of the extraction process using response surface methodology (RSM)." Nat. Prod. Res., 2: 1-8, 2018.

26. Li, Q., S. Wu, C. Wang, Y. Yi, W. Zhou, H. Wang, Z. Tan. "Ultrasonic assisted extraction of sinomenine from sinomenium acutum using magnetic Ionic liquids coupled with further purification by reversed micellar extraction". Process Biochem., 58: 282-288, 2017.

27. Adeel, S., M. Zuber, F.U. Rehman, K.M. Zia. "Microwave aassisted extraction and dyeing of chemical and bio-mordanted cotton fabric 
using harmal seeds as a source of natural dye." Environ. Sci. Pollu. Res., 25(11): 11100-11110, 2018.

28. Bronzato, M., A. Zoleo, B. Biondi,S.A. Centeno "An Insight into the metal coordination and spectroscopic properties of artistic fe and fe/cu logwood ınks."Spectrochım. Acta. A., 153: 522-529, 2016.

29. Kahr, B., S. Lovell, J.A. Subramony."The progress of logwood extract”.Chirality: Pharm. Biol. Chem. Cons. Mol. Asym., 10(1-2): 6677, 1998.

30. Ramandi, N.F., A. Ghassempour, N.M. Najafi, E. Ghasemi. "Optimization of ultrasonic assisted extraction of fatty acids from borago officinalis I. flower by central composite design". Arab. J. Chem., 10:S23-S27, 2017.

31. Ismal, O.E., L. Yildirim, E. Ozdogan. "Use of almond shell extracts plus biomordants as effective textile dye”.J. Clean. Prod.,70:61-67, 2014

32. Ismal, O.E."Greener natural dyeing pathway using a by-product of olive oil prina and biomordants." Fibers Polym., 18(4): 773-785, 2017.

33. Adeel, S., K.M. Zia, M. Abdullah, F.U. Rehman, M. Salman, M. Zuber "Ultrasonic assisted Improved extraction and dyeing of mordanted silk fabric using neem bark as source of natural colourant". Nat. Prod. Res., 33(14): 2060-2072, 2019.
34. Yusuf, M., F. Mohammad, M. Shabbir, M.A. Khan. "Eco-dyeing of wool with Rubia cordifolia root extract: assessment of the effect of acacia catechuas bio-mordant on color and fastness properties". Text. Cloth. Sustain., 2(1): 2-9, 2017.

35. Islam, S.U., L.J. Rather, M. Shabbir, J. Sheikh, M.N. Bukhari, M.A Khan, F. Mohammad. "Exploiting the potential of polyphenolic biomordants in environmentally friendly coloration of wool with natural dye from butea monosperma flower extract”. J. Nat. Fibers., 1: 1-2, 2018.

36. Ganesan, P., T. Karthik. "Analysis of colour strength, colour fastness and anti-microbial properties of silk fabric dyed with natural dye from red prickly pear fruit". J. Text. I., 108: 1173-1179, 2017.

37. Zia, K.M., S. Adeel, F. Rehman, H. Aslam, M.K. Khosa, M. Zuber. Influence of ultrasonic radiation on extraction and green dyeing of mordanted cotton using neem bark extract." J. Ind. Eng. Chem., $77: 317-322,2019$

38. Islam, S., L.J. Rather, M. Shabbir, J. Sheikh, M.N. Bukhari, M.A. Khan, F. Mohammad. "Exploiting the potential of polyphenolic bio-mordants in environmentally friendly coloration of wool with natural dye from butea monosperma flower extract”. J. Nat. Fibers., 1(12):512-523, 2018. 